\title{
Faktor-Faktor Yang Mempengaruhi Perilaku Pemeriksaan Payudara Sendiri (SADARI) Pada Mahasiswi Non Kesehatan UIN Antasari Banjarmasin
}

\author{
Factors Affecting the Behavior of Self Breast Examination (BSE) \\ in Non-Medical Student UIN Antasari Banjarmasin
}

Septi Anggraini*, Eka Handayani

Fakultas Kesehatan Masyarakat Universitas Islam Kalimantan (UNISKA) MAB Banjarmasin Jl. Adhyaksa No. 2, Kayu Tangi, Kota Banjarmasin, Kalimantan Selatan

*korespondensi : septi_0323@yahoo.co.id

\begin{abstract}
Cancer is one of the leading causes of death worldwide. In Indonesia, more than $80 \%$ of breast cancer cases are found at an advanced stage, where treatment is difficult. Therefore, it is necessary to take preventative measures with early diagnosis through regular routine checks, one of which is by Self Breast Examination (BSE). This study was conducted to determine the factors that influence the behavior of BSE in non-medical students UIN Antasari Banjarmasin with a cross sectional study design with a sample of 50 female students. Data processing analysis includes univariate analysis, bivariate analysis and multivariate analysis with multiple logistic regression statistical tests. Descriptively obtained results that only 13 people (26\%) did BSE, respondents' knowledge 38\% in good category, attitude towards BSE $84 \%$ positive, source of information about BSE $22 \%$ in many categories, perceptions of family support $28 \%$ supporting and perception about peer support $24 \%$ supports. To determine the factors that influence BSE, multiple logistic regression statistical tests were performed which showed the results that there was a joint influence between knowledge, exposure to information sources, perceptions of family and peer support on BSE behavior with a large influence of $35.6 \%$. To improve the behavior of BSE, it is necessary to increase knowledge, information sources, family and peer support together.
\end{abstract}

Keywords: Knowledge, attitude, Family support, Information Exposure, BSE

\section{Pendahuluan}

Berdasarkan Data GLOBOCAN, International Agency for Research on Cancer (IARC), diketahui bahwa pada tahun 2012 terdapat 14.067 .894 kasus baru kanker dan 8.201.575 kematian akibat kanker di seluruh dunia. kanker payudara, kanker prostat, dan kanker paru merupakan jenis kanker dengan persentase kasus baru (setelah dikontrol dengan umur) tertinggi. Sementara itu, kanker paru dan kanker payudara merupakan penyebab kematian (setelah dikontrol dengan umur) tertinggi akibat kanker. Pada penduduk perempuan, kanker payudara masih menempati urutan pertama kasus baru dan kematian akibat kanker, yaitu sebesar $43,3 \%$ dan $12,9 \%$. $(1,2)$.

Penyakit kanker merupakan salah satu penyebab kematian utama di seluruh dunia. Kanker payudara merupakan salah satu jenis kanker terbanyak di Indonesia. Berdasarkan Pathological Based Registration di Indonesia, Kanker payudara menempati urutan pertama dengan frekuensi relatif sebesar $18,6 \%$. (3).

Berdasarkan data Riskesdas 2013, prevalensi kanker di Indonesia adalah sebesar 1,4 per 1.000 penduduk serta merupakan penyebab kematian nomor 7 $(5,7 \%)$ dari seluruh penyebab kematian. Estimasi insidens kanker payudara di Indonesia sebesar 40 per 100.000 perempuan. Jenis kanker tertinggi pada pasien rawat inap di rumah sakit seluruh Indonesia tahun 2010 adalah kanker payudara $(28,7 \%)$, disusul kanker leher rahim $(12,8 \%)$. (4).

Data RSUD Ulin Banjarmasin tahun 2013, kanker payudara termasuk dalam 10 penyakit terbanyak yang menempati urutan ke-9 di Kalimantan Selatan. Kasus baru terus meningkat dari tahun ke tahun yang diketahui pada tahun 2008 sebanyak 77 kasus, tahun 2009 sebanyak 83 kasus, tahun 2010 sebanyak 103 kasus, tahun 2011 sebanyak 124 kasus, dan tahun 2012 sebanyak 125 kasus. (5) 
Di Indonesia, lebih dari $80 \%$ kasus kanker payudara ditemukan berada pada stadium yang lanjut, dimana upaya pengobatan sulit dilakukan. Oleh karena itu perlu pemahaman tentang upaya pencegahan, diagnosis dini, pengobatan kuratif maupun paliatif serta upaya rehabilitasi yang baik, agar pelayanan pada penderita dapat dilakukan secara optimal. Tingginya prevalensi kanker di Indonesia perlu dicermati dengan tindakan pencegahan dan deteksi dini. Kasus kanker yang ditemukan pada stadium dini serta mendapat pengobatan yang cepat dan tepat akan memberikan kesembuhan dan harapan hidup lebih lama. Oleh karena itu, penting dilakukan pemeriksaan rutin secara berkala sebagai upaya pencegahan dan deteksi dini kanker. (6).

Salah satu upaya pencegahan kanker payudara adalah melalui pencegahan sekunder yaitu melakukan skrining kanker payudara yang merupakan pemeriksaan atau usaha untuk menemukan abnormalitas yang mengarah pada kanker payudara pada seseorang atau kelompok orang yang tidak mempunyai keluhan. Beberapa tindakan untuk skrining adalah Periksa Payudara Sendiri (SADARI), Periksa Payudara Klinis (SADANIS) dan Mammografi skrining. (6).

Pemeriksaan Payudara Sendiri (SADARI) adalah suatu prosedur untuk mengetahui kelainan-kelainan pada payudara dengan inspeksi secara berkala yang sebaiknya dilakukan oleh setiap perempuan tiap bulan dimulai pada usia 20 tahun atau sejak menikah. Salah satu kelompok yang telah mencapai usia tersebut adalah mahasiswi. Pada saat itu seorang mahasiswi memasuki tahap perkembangan remaja akhir (adolescence). (7).

Mahasiswi yang menempuh pendidikan dalam bidang kesehatan pada umumnya telah memperoleh pengetahuan tentang SADARI sehingga akan cenderung membentuk sikap yang positif yang tercermin dalam perilakunya. Karena adanya pengetahuan tersebut merupakan domain yang sangat penting dalam membentuk tindakan seseorang. (8).

Penelitian yang dilakukan oleh Nugraheni (2010) menunjukkan bahwa tingkat pengetahuan SADARI dan perilaku SADARI dikalangan mahasiswi medis adalah baik. Sedangkan hasil penelitian
Baswedan (2014) pada mahasiswi non kesehatan di Universitas Muhammadiyah Yogyakarta menunjukkan bahwa sebesar 49,8\% mahasiswi memiliki perilaku SADARI kurang, perilaku cukup sejumlah $43,5 \%$ dan perilaku SADARI baik sebesar $6,7 \%$. $(9,10)$.

Universitas Islam Negeri (UIN)

Antasari Banjarmasin merupakan salah satu Perguruan Tinggi Negeri di kota Banjarmasin. Tidak dapat dipungkiri bahwa kesehatan sangatlah penting bagi setiap orang tak terkecuali bagi mahasiswi yang sedang menuntut ilmu di UIN Antasari Banjarmasin. Berdasarkan hasil studi pendahuluan yaitu wawancara terhadap 6 mahasiswi Fakultas non kesehatan di UIN Antasari Banjarmasin, berusia diatas 19 tahun yang dilakukan secara acak untuk mengetahui perilaku SADARI, didapatkan hasil bahwa 4 orang mahasiswi mengatakan tidak pernah melakukan SADARI karena memang tidak mengetahui apa itu SADARI, cara melakukan dan manfaatnya sedangkan 2 mahasiswi mengatakan bahwa mereka pernah melakukan SADARI karena mempunyai keluarga dengan riwayat tumor dan kanker payudara.

\section{Metode Penelitian}

Penelitian ini merupakan penelitian survey analitik dengan pendekatan cross sectional. Populasi dalam penelitian ini adalah mahasiswi semester 4 Universitas Islam Negeri (UIN) Antasari Banjarmasin. Sampel pada penelitian ini adalah sebagian dari populasi dengan sampel yaitu sebanyak 50 orang mahasiswi. Instrumen penelitian menggunakan kuesioner.

Analisis pengolahan data meliputi analisis univariat, analisis bivariat dan analisis multivariat dengan uji statistik multiple logistic regression.

\section{Hasil Penelitian}

\section{a. Analisis Univariat}

1) Perilaku SADARI

Tabel 1. Distribusi Frekuensi Perilaku SADARI Mahasiswi UIN Antasari Banjarmasin

\begin{tabular}{lcc}
\hline \multicolumn{1}{c}{ Perilaku SADARI } & $\mathbf{n}$ & $\%$ \\
\hline Melakukan SADARI & 13 & 26 \\
\hline Tidak Melakukan & 37 & 74 \\
\hline Jumlah & 50 & 100 \\
\hline
\end{tabular}

Berdasarkan tabel. 1 diketahui bahwa responden yang melakukan SADARI masih 
tergolong sedikit. Sebagian besar responden tidak melakukan SADARI yaitu sebanyak 37 responden (74\%). Kategori responden yang tidak melakukan SADARI yaitu responden yang sama sekali belum pernah melakukan tindakan SADARI dan responden yang sudah pernah melakukan namun salah dalam tata cara SADARI dan tidak rutin dalam pelaksanaanya.

\section{2) Pengetahuan tentang SADARI}

Tabel 2. Distribusi Frekuensi Pengetahuan Responden Tentang SADARI di UIN Antasari Banjarmasin

\begin{tabular}{llc}
\hline Pengetahuan tentang SADARI & $\mathbf{n}$ & $\%$ \\
\hline Baik & 19 & 38 \\
\hline Kurang & 31 & 62 \\
\hline Jumlah & 50 & 100 \\
\hline
\end{tabular}

Berdasarkan tabel 2 diketahui bahwa sebagian besar responden memiliki pengetahuan kurang tentang SADARI $(62 \%)$. Pengetahuan yang kurang terutama dalam hal bagaimana cara dan waktu pelaksanaan SADARI.

3) Sikap terhadap SADARI

Tabel 3. Distribusi Frekuensi Sikap Responden Terhadap SADARI di UIN Antasari Banjarmasin

\begin{tabular}{lcc}
\hline Sikap tentang SADARI & $\mathbf{n}$ & $\%$ \\
\hline Positif & 42 & 84 \\
\hline Negatif & 8 & 16 \\
\hline Jumlah & 50 & 100 \\
\hline
\end{tabular}

Tabel 3 menunjukkan bahwa sebagian besar yaitu sebanyak 42 responden (84\%) memiliki sikap positif terhadap SADARI.

4) Keterpaparan Sumber Informasi tentang SADARI

Tabel 4. Distribusi Frekuensi Keterpaparan Sumber Informasi tentang SADARI pada mahasiswi UIN Antasari Banjarmasin

\begin{tabular}{|l|c|c|}
\hline Sumber informasi tentang SADARI & $\mathbf{n}$ & $\%$ \\
\hline Banyak & 11 & 22 \\
\hline Sedikit & 39 & 78 \\
\hline Jumlah & 50 & 100 \\
\hline
\end{tabular}

Berdasarkan tabel 4 diketahui bahwa sebagian besar responden (78\%) masih dalam kategori sedikit dalam memperoleh informasi tentang SADARI. Informasi tentang SADARI bisa diperoleh dari berbagai sumber yaitu melalui media elektronik, surat kabar, majalah, petugas kesehatan, materi kuliah, lingkungan dan sebaginya. Namun pada hasil penelitian ini hanya sebagian kecil yang terpapar oleh sumber informasi yang banyak tentang SADARI. Kategori sumber informasi yang banyak adalah apabila responden memperoleh informasi dari berbagai sumber yaitu $>50 \%$.

5) Persepsi tentang dukungan keluarga terhadap perilaku SADARI

Tabel 5. Distribusi Frekuensi Persepsi Dukungan Keluarga Terhadap SADARI di UIN Antasari Banjarmasin

\begin{tabular}{lcc}
\hline Persepsi Dukungan Keluarga & $\mathbf{n}$ & $\%$ \\
\hline Mendukung & 14 & 28 \\
\hline Kurang Mendukung & 36 & 72 \\
\hline Jumlah & 50 & 100 \\
\hline
\end{tabular}

Tabel 5 menunjukkan bahwa sebagian besar yaitu sebanyak 32 (72\%) responden kurang mendapat dukungan dari keluarga untuk melakukan SADARI. Dukungan keluarga meliputi informasi tentang SADARI, cara melakukan dan anjuran untuk melakukan SADARI.

6) Persepsi tentang dukungan teman sebaya terhadap Perilaku SADARI.

Tabel 6. Distribusi Frekuensi Persepsi Dukungan Teman Sebaya Terhadap SADARI di UIN Antasari Banjarmasin

\begin{tabular}{lcc}
\hline $\begin{array}{c}\text { Persepsi Dukungan } \\
\text { Teman Sebaya }\end{array}$ & $\mathbf{n}$ & $\%$ \\
\hline Mendukung & 12 & 24 \\
\hline Kurang Mendukung & 38 & 76 \\
\hline Jumlah & 50 & 100 \\
\hline
\end{tabular}

Berdasarkan tabel 6 diketahui bahwa sebagian besar yaitu sebanyak 38(76\%) responden kurang mendapat dukungan dari teman sebaya untuk melakukan SADARI. Dukungan teman sebaya meliputi penyampaian informasi tentang SADARI, cara melakukan dan anjuran untuk melakukan SADARI.

\section{b. Analisis Bivariat}

Hasil yang diperoleh dari uji regresi logistik dapat dilihat pada tabel di bawah ini : Tabel 7. Hasil Rekapitulasi Uji Pengaruh Antara Beberapa Faktor Terhadap Perilaku SADARI Pada Mahasiswi Non Kesehatan UIN Antasari Banjarmasin 


\begin{tabular}{ccccc}
\hline No & Variabel & p value & Exp (B) & \multicolumn{1}{c}{ Ket } \\
\hline 1 & Pengetahuan & 0,011 & 6,075 & $\begin{array}{l}\text { Ada } \\
\text { Pengaruh }\end{array}$ \\
\hline 2 & Sikap & 0,999 & 1,583 & $\begin{array}{l}\text { Tidak Ada } \\
\text { Pengaruh }\end{array}$ \\
\hline 3 & $\begin{array}{l}\text { Sumber } \\
\text { informasi }\end{array}$ & 0,003 & 9,625 & $\begin{array}{l}\text { Ada } \\
\text { Pengaruh }\end{array}$ \\
\hline 4 & $\begin{array}{l}\text { Dukungan } \\
\text { Keluarga }\end{array}$ & 0,004 & 8,627 & $\begin{array}{l}\text { Ada } \\
\text { Pengaruh }\end{array}$ \\
\hline 5 & $\begin{array}{l}\text { Dukungan } \\
\text { Teman Sebaya }\end{array}$ & 0,006 & 7,647 & $\begin{array}{l}\text { Ada } \\
\text { Pengaruh }\end{array}$ \\
\hline
\end{tabular}

Dari hasil analisis pengaruh variabel bebas terhadap variabel terikat, dapat disimpulkan bahwa perilaku SADARI di tentukan oleh faktor pengetahuan, Keterpaparan sumber informasi, persepsi tentang dukungan keluarga dan dukungan teman sebaya $(p<0,05)$, Sedangkan faktor sikap tidak berpengaruh terhadap perilaku SADARI $(p>0,05)$. Variabel yang mempunyai pengaruh terbesar adalah variabel keterpaparan sumber informasi dengan $\operatorname{Exp}(B)=9,625$ artinya sumber informasi yang banyak tentang SADARI mempunyai kemungkinan terjadinya perilaku SADARI 9,6 kali lebih besar daripada sumber informasi sedikit.

\section{c. Analisis Multivarat}

Analisis Pengaruh beberapa faktor terhadap perilaku SADARI pada mahasiswi UIN Antasari Banjarmasin yaitu dengan uji multiple regresi logistic. Melalui uji tersebut diharapkan dapat memperoleh model regresi yang baik dan mampu menjelaskan variabel yang berpengaruh terhadap perilaku SADARI.

Setelah dilakukan analisis multivariat menggunakan metode Enter dengan memasukkan variabel bebas secara bersama-sama, diperoleh hasil bahwa nilai signifikansi secara bersama-sama bermakna $(p=0,003)$ dengan nilai $R$ Square $=0,356$ yang berarti variabel pengetahuan, keterpaparan sumber informasi, persepsi tentang dukungan keluarga dan teman sebaya berpengaruh sebesar 35,6\% terhadap perilaku SADARI.

\section{Pembahasan}

\section{a. Perilaku SADARI}

Berdasarkan hasil analisis data diperoleh hasil bahwa sebagian besar responden tidak melakukan SADARI yaitu sebanyak 37 responden (74\%) dan yang melakukan SADARI sebanyak 13 responden (26\%).

Banyaknya responden yang tidak melakukan SADARI disebabkan karena beberapa alasan diantaranya karena tidak tahu bagaimana cara melakukan SADARI, kurang memperhatikan masalah upaya pencegahan yang terkait masalah kelainan pada payudara dan ada beberapa responden yang menyatakan bahwa mereka malu dan takut untuk melakukan SADARI.

Hasil penelitian ini sejalan dengan penelitian yang dilakukan oleh Angrainy (2017) yang menunjukkan hasil bahwa remaja putri yang melakukan SADARI masih tergolong sedikit, yaitu dari 50 responden yang diteliti, hanya $9(18 \%)$ responden yang melakukan SADARI dan 41 responden $(82 \%)$ tidak melakukan SADARI. Masih rendahnya perilaku SADARI pada remaja puteri tersebut antara lain disebabkan karena faktor pengetahuan dan sikap. Hasil penelitian menunjukkan sebagian besar $(62 \%)$ remaja putri memiliki pengetahuan yang kurang tentang SADARI dan sebesar $64 \%$ memiliki sikap negatif terhadap SADARI (11).

\section{b. Pengaruh Pengetahuan Terhadap Perilaku SADARI \\ Hasil analisis data menunjukkan} bahwa dari 50 responden, sebanyak 31 $(62 \%)$ responden memiliki pengetahuan yang kurang tentang SADARI. Berdasarkan hasil penelitian diketahui bahwa sebagian besar responden tidak tahu bagaimana cara dan waktu melakukan SADARI. Beberapa responden ada yang berpendapat bahwa SADARI hanya bisa dilakukan pada wanita yang sudah menikah dan berusia lebih dari 30 tahun.

Berdasarkan hasil uji statistik di peroleh nilai $p$-value $=0,011(p<\alpha)$ yang berarti ada pengaruh pengetahuan terhadap perilaku SADARI.

Pengetahuan atau kognitif merupakan domain yang sangat penting dalam membentuk tindakan seseorang. Pengetahuan sangat penting di dalam seseorang mengambil keputusan karena tindakan yang didasarkan atas pengetahuan memberikan konsekuensi yang lebih baik bagi pengambil keputusan. Pengetahuan merupakan faktor predisposisi yang menentukan perilaku seseorang (8). 
Penelitian yang dilakukan oleh Setiawan (2012) mendapatkan hasil bahwa ada hubungan yang signifikan antara pengetahuan responden dengan tindakan pemeriksaan kanker payudara dini. Hasil penelitian ini juga sejalan dengan hasil penelitian Angrainy (2017) yang menyatakan bahwa terdapat hubungan pengetahuan dengan pelaksanaan SADARI pada remaja putri dengan nilai $p$ value $=0,007$. Ada perbedaan proporsi pemeriksaan SADARI antara pengetahuan remaja yang berpengetahuan baik dan kurang. Pada responden dengan pengetahuan baik sebanyak 7 (14\%) pernah melakukan SADARI sedangkan pada responden yang berpengetahuan kurang sebanyak 2 (4\%) pernah melakukan pemeriksaan SADARI $(12,11)$.

Keinginan untuk melakukan pendeteksian dini salah satunya SADARI sangat dipengaruhi oleh pengetahuan responden mengenai hal yang berhubungan dengan pendeteksian dini kanker payudara khususnya SADARI. Oleh karena itu pengetahuan yang ada dalam diri mahasiswi akan sangat menentukan bagaimana mereka menerapkannya dalam bentuk perilaku. (13).

\section{c. Pengaruh Sikap Terhadap Perilaku SADARI}

Hasil analisis data menunjukkan bahwa sebagian besar responden yaitu sebanyak 42 orang (84\%) memiliki sikap positif terhadap SADARI. Sebagian besar responden setuju bahwa SADARI merupakan salah satu cara untuk deteksi dini kelainan pada payudara. Walaupun sebagian besar memiliki sikap positif terhadap SADARI, namun masih ada beberapa responden yaitu sebanyak 8 orang yang memiliki sikap negatif terhadap SADARI. Mereka beranggapan bahwa SADARI bukan salah satu cara untuk deteksi dini kanker payudara dan beranggapan bahwa seharusnya hanya dilakukan pada wanita yang sudah menikah.

Berdasarkan hasil uji statistik di peroleh nilai $p$-value $=0,999(p>\alpha)$ yang berarti tidak ada pengaruh sikap terhadap perilaku SADARI.

Hasil penelitian ini sejalan dengan penelitian yang dilakukan oleh Septiani yang menyatakan bahwa tidak ada hubungan yang bermakna antara sikap dengan perilaku siswi dalam melakukan pendeteksian dini yaitu SADARI dengan nilai $p$-value $=0,3$. Pada penelitian ini sebanyak $(82,7 \%)$ responden bersikap positif dan memiliki perilaku SADARI yang negatif, demikian pula sebanyak $(91,7 \%)$ responden yang bersikap negatif, memiliki perilaku SADARI yang negatif pula. (13).

Menurut Newcomb dalam Notoatmodjo seorang ahli psikologi sosial, bahwa sikap merupakan kesiapan atau kesediaan untuk bertindak dan bukan merupakan pelaksanaan motif tertentu. Sikap merupakan reaksi terhadap objek di lingkungan tertentu sebagai suatu pengembangan terhadap objek. Perilaku cenderung akan terbentuk melalui suatu sikap yang positif terhadap perilaku tersebut. Sikap positif kebanyakan mendukung seseorang dalam bertindak. Apabila seseorang tersebut sudah mempunyai sikap positif terhadap sesuatu namun tidak melakukannya hal ini dikarenakan faktor dari dalam individu. (8).

Seperti halnya pada hasil penelitian ini, bahwa tidak ada pengaruh sikap terhadap perilaku, padahal sebagian besar mahasiswi mempunyai sikap positif namun tidak melaksanakan SADARI hal ini dikarenakan mereka tidak tahu cara/tekniknya, merasa malu dan beranggapan bahwa dirinya tidak berisiko sehingga merasa tidak perlu.

\section{d. Keterpaparan Sumber Informasi Tentang SADARI}

Berdasarkan hasil analisis data diketahui bahwa hanya sebagian kecil responden yang memperoleh sumber informasi yang banyak tentang SADARI (22\%). Informasi mengenai SADARI diperoleh responden dari berbagai sumber. Pada penelitian ini responden diperkenankan untuk memilih lebih dari satu sumber informasi. Adapun sumber informasi yang didapat tentang SADARI sebagian besar yaitu berasal dari keluarga, media sosial dan teman.

Responden pada penelitian ini adalah mahasiswi non kesehatan, dimana mahasiswi ini tidak mendapat mata kuliah yang khusus tentang kesehatan dan bersifat wajib, sehingga informasi yang didapat terkait masalah SADARI masih kurang dan 
sebagian besar menyatakan tidak pernah mendapat informasi tentang SADARI dari berbagai seminar ataupun penyuluhan.

Berdasarkan hasil uji statistik di peroleh nilai $p$-value $=0,003(p<\alpha)$ yang berarti ada pengaruh sumber informasi terhadap perilaku SADARI.

Informasi dapat diperoleh dari pendidikan formal maupun non formal. Sumber informasi dapat berupa media elektronik seperti televisi, radio, surat kabar, buku, majalah, dan lain-lain. Seseorang yang mudah mengakses informasi akan lebih cepat mendapat pengetahuan. Majunya teknologi dapat mempengaruhi pengetahuan masyarakat yang dapat memberi pengaruh sehingga menghasilkan perubahan atau peningkatan pengetahuan yang diharapkan mampu mempengaruhi tindakan.

Hasil penelitian ini sejalan dengan penelitian Desanti yang mengatakan informasi tentang SADARI adalah variabel yang paling berhubungan dengan perilaku SADARI ( $p$ value $=0,000$ ). Sumber Informasi merupakan hal yang penting, karena dengan adanya informasi yang didapatkan maka akan memberikan pengetahuan terhadap responden dan juga bisa merubah sikap dari responden tersebut. (14).

e. Persepsi tentang dukungan keluarga terhadap perilaku SADARI

Hasil analisis persepsi remaja tentang dukungan keluarga terhadap perilaku SADARI menunjukkan bahwa sebagian besar keluarga kurang mendukung terhadap SADARI (72\%). Hanya Sebagian kecil $(28 \%)$ responden menyatakan bahwa keluarga pernah memberikan informasi tentang SADARI, cara melakukan dan menganjurkan untuk melakukan SADARI.

Berdasarkan hasil uji statistik di peroleh nilai $p$-value $=0,004(p<\alpha)$ yang berarti ada pengaruh dukungan keluarga terhadap perilaku SADARI.

Menurut teori Lawrence Green dalam Notoatmodjo, perilaku kesehatan seseorang atau masyarakat di pengaruhi oleh dua faktor pokok, yakni faktor perilaku dan faktor di luar perilaku (non behavior cause). Perilaku itu sendiri terbentuk dari tiga faktor, salah satunya faktor penguat (reinforcing factor). Faktor-faktor yang mendorong atau memperkuat terjadinya perilaku pada seseorang individu yaitu faktor perilaku dari tokoh masyarakat, tokoh agama, para petugas kesehatan dan juga orang-orang disekitarnya yaitu orang tua atau keluarga dari individu itu sendiri. Keluarga merupakan sumber dukungan sosial, karena dalam hubungan keluarga tercipta hubungan yang saling mempercayai. (8).

Dukungan keluarga dalam perilaku SADARI berupa pemberian informasi secara verbal maupun non verbal, pemberian bantuan tingkah laku yang didapat dari hubungan sosial yang akrab. Keluarga berfungsi sebagai sebuah kolektor (pengumpul) dan disseminator (penyebar) informasi tentang berbagai hal. Menjelaskan tentang pemberian saran, sugesti, informasi yang dapat digunakan untuk mengungkapkan dan menyelesaikan suatu masalah. Manfaat dari dukungan ini adalah dapat menekan munculnya suatu pemahaman karena informasi yang diberikan dan dapat menyumbangkan sugesti dan aksi pada individu. (8).

Hasil penelitian ini sejalan dengan penelitian Fatayati (2015) yang menyatakan ada hubungan dukungan sosial terhadap perilaku SADARI. Variabel yang berhubungan tersebut adalah dukungan suami, dukungan orang tua dan dukungan tenaga kesehatan. Ada hubungan dukungan orang tua dengan kebiasaan SADARI dengan nilai $p$ value $=0,028$. (15).

f. Persepsi tentang dukungan teman sebaya terhadap perilaku SADARI.

Berdasarkan hasil jawaban responden diketahui bahwa pada umumnya responden menyatakan bahwa teman sebaya kurang mendukung terhadap SADARI. Hanya sebagian kecil reponden yang mendapat dukungan dari teman sebaya tentang manfaat dan cara melakukan SADARI. Berdasarkan hasil analisis, pada responden yang mendapat dukungan berupa pemberian informasi tentang SADARI dari teman sebaya, lebih banyak yang melakukan tindakan SADARI dibandingkan dengan responden yang tidak mendapat dukungan dari teman sebaya.

Berdasarkan hasil uji statistik di peroleh nilai $p$-value $=0,006(p<\alpha)$ yang berarti ada pengaruh dukungan teman sebaya terhadap perilaku SADARI. 
Faktor lain yang mempengaruhi kehidupan remaja adalah teman sebaya. Bahkan teman sebaya cenderung lebih berpengaruh dibandingkan keluarga terhadap pengetahuan dan tindakan remaja. Teman sebaya dijadikan role model dalam hal perilaku bagi anak usia remaja. Remaja lebih banyak berada di luar rumah dengan teman-teman sebaya sebagai kelompok. Teman sebaya dapat memberikan pengaruh terhadap sikap, pembicaraan, minat, penampilan, dan perilaku (16).

Hasil penelitian ini sejalan dengan penelitian yang dilakukan Sari (2014) yang menyatakan bahwa ada hubungan yang bermakna antara dukungan orang terdekat (lbu, kakak, teman, guru) dengan tindakan SADARI pada remaja putri dengan $p$ value $=$ 0,000 . Remaja putri tidak pernah melakukan periksa payudara sendiri (SADARI), hal ini disebabkan antara lain karena dukungan orang terdekat remaja putri kurang karena orang terdekat (ibu,kakak,teman dan guru) remaja putri tidak pernah menyarankan untuk melakukan SADARI (17).

\section{Kesimpulan}

1. Perilaku SADARI oleh mahasiswi UIN Antasari Banjarmasin masih sangat rendah yaitu dari 50 responden, sebanyak 37 (74\%) tidak melakukan SADARI.

2. Secara deskriptif diperoleh hasil yaitu pengetahuan responden $62 \%$ dalam kategori kurang, sikap terhadap SADARI $84 \%$ positif, sumber informasi tentang SADARI $78 \%$ dalam kategori sedikit, persepsi tentang dukungan keluarga $72 \%$ kurang mendukung dan persepsi tentang dukungan teman sebaya yaitu sebanyak $76 \%$ dalam kategori kurang mendukung.

3. Ada pengaruh pengetahuan terhadap perilaku SADARI $(p=0,011)$

4. Tidak Ada pengaruh sikap terhadap perilaku SADARI $(p=0,999)$

5. Ada pengaruh keterpaparan sumber informasi terhadap perilaku SADARI $(p=0,003)$

6. Ada pengaruh persepsi tentang dukungan keluarga terhadap perilaku SADARI $(p=0,004)$

7. Ada pengaruh persepsi tentang dukungan teman sebaya terhadap perilaku SADARI $(p=0,006)$
Faktor yang berpengaruh secara bersama-sama terhadap perilaku SADARI adalah pengetahuan, keterpaparan sumber informasi, persepsi tentang dukungan keluarga dan teman sebaya. Untuk meningkatkan perilaku SADARI, maka perlu peningkatan pengetahuan, sumber informasi, dukungan keluarga dan teman sebaya secara bersama-sama.

\section{Daftar Pustaka}

1. International Agency for Research on Cancer (IARC)/WHO. Estimated cancer incidence, mortality, and prevalence worldwide in 2012. Diakses melaluihttp://globocan.iarc.fr/Pages/fact sheets_population.aspx pada tanggal 16 April 2017

2. Wahidin, Mugi. 2015. Deteksi Dini Kanker Leher Rahim dan Kanker Payudara di Indonesia 2007-2014. Buletin Jendela Data \& Informasi Kesehatan, semester 1:1-11

3. Kementrian Kesehatan RI.Situasi Penyakit Kanker. Jakarta: Pusat Data dan Informasi. 2015

4. Kementerian Kesehatan RI Riset Kesehatan Dasar (RISKESDAS). Jakarta: Badan Litbang Kemenkes RI. 2013

5. Azlina F, Meitria, Fatimatuzzahrah. Perbedaan Tingkat Pengetahuan Tentang Pemeriksaan Payudara Sendiri (SADARI) Sebelum dan Sesudah Pemberian Leaflet Pada Mahasiswi FMIPA UNLAM. Fakultas Kedokteran Universitas Lambung Mangkurat. 2014

6. Kementerian Kesehatan RI. Panduan Penatalaksanaan Kanker Payudara. Jakarta: Komite Penanggulangan Kanker Nasional. 2015

7. Sarwono,S. Psikologi Remaja. Jakarta: Rajawali Pers. 2010

8. Notoatmodjo S. Promosi Kesehatan dan Perilaku Kesehatan. Jakarta: PT Rineka Cipta. 2012

9. Nugraheni, A. Hubungan Tingkat Pengetahuan Tentang SADARI Dengan Perilaku SADARI sebagai Deteksi Dini Kanker Payudara Pada Mahasiswi DIV Kebidanan FK UNS. Universitas Negeri Surakarta. 2010

10. Baswedan, RH dan Ekorini L. Hubungan Tingkat Pengetahuan Tentang Pemeriksaan Payudara Sendiri 
(SADARI) Pada Mahasiswi Non

Kesehatan di Universitas

Muhammadiyah Yogyakarta. Jurnal Biomedika, 6(1) : 1-6. 2014

11. Angrainy R. Hubungan Pengetahuan, Sikap tentang SADARI Dalam Mendeteksi Dini Kanker Payudara Pada Remaja. Journal Endurance, 2(2) : 232238. 2017

12. Setiawan, F.S. Hubungan Pengetahuan dan Deteksi Dini (SADARI) dengan Keterlambatan Penderita Kanker Payudara Melakukan Pemeriksaan Di RSUD Kraton Kabupaten Pekalongan. STIKES Muhammadiyah Pekajangan. 2012

13. Septiani $S$ dan Mahyar S. Faktor Faktor Yang Berhubungan Dengan Perilaku Pemeriksaan Payudara Sendiri (SADARI) Pada Siswa SMAN 62 Jakarta. Jurnal IImiah Kesehatan, 5(1) :31-35. 2013

14. Desanti, O. I., Sunarsih, I., \& Supriyati. Persepsi Wanita Berisiko Kanker

Payudara Tentang Pemeriksaan Payudara Sendiri Di Kota Semarang, Jawa Tengah. Berita Kedokteran Masyarakat, 26(3), 152-161. 2010

15. Fatayati, A. Hubungan Dukungan Sosial Terhadap Perilaku Pemeriksaan Payudara Sendiri (SADARI) Di Wilayah Kerja Puskesmas Manyaran Kabupaten Wonogiri. Tesis. Universitas Sebelas Maret Surakarta. 2015

16. Narendra, M. S. Buku Ajar 1 Tumbuh Kembang Anak dan Remaja Edisi Pertama IDAI. Jakarta: Sagung Seto. 2002

17. Sari Y.P, Namora L \& Eddy S. Determinan Perilaku SADARI Remaja Putri Dalam Upaya Deteksi Dini Kanker Payudara Di SMK Negeri 8 Medan. FKM Universitas Sumatera Utara. 2014 